\title{
Bacillus horneckiae sp. nov., isolated from a spacecraft-assembly clean room
}

\section{Correspondence \\ Kasthuri Venkateswaran kjvenkat@jpl.nasa.gov}

\author{
Parag Vaishampayan, ${ }^{1}$ Alexander Probst, ${ }^{1} \dagger$ Srinivasan Krishnamurthi, ${ }^{2}$ \\ Sudeshna Ghosh, ${ }^{1}$ Shariff Osman, ${ }^{1} \ddagger$ Alasdair McDowall, ${ }^{3}$ \\ Arunachalam Ruckmani, ${ }^{2}$ Shanmugam Mayilraj ${ }^{2}$ \\ and Kasthuri Venkateswaran ${ }^{1}$
}

\author{
${ }^{1}$ Biotechnology and Planetary Protection Group, Jet Propulsion Laboratory, California Institute of \\ Technology, Pasadena, CA 91109, USA \\ ${ }^{2}$ Microbial Type Culture Collection and Gene Bank (MTCC), Institute of Microbial Technology, \\ Chandigarh 160 036, India \\ ${ }^{3}$ Broad and Beckman Research Centers, California Institute of Technology, Pasadena, CA 91125, \\ USA
}

Five Gram-stain-positive, motile, aerobic strains were isolated from a clean room of the Kennedy Space Center where the Phoenix spacecraft was assembled. All strains are rod-shaped, sporeforming bacteria, whose spores were resistant to UV radiation up to $1000 \mathrm{~J} \mathrm{~m}^{-2}$. The spores were subterminally positioned and produced an external layer. A polyphasic taxonomic study including traditional biochemical tests, fatty acid analysis, cell-wall typing, lipid analyses, 16S rRNA gene sequencing and DNA-DNA hybridization studies was performed to characterize these novel strains. 16S rRNA gene sequencing and lipid analyses convincingly grouped these novel strains within the genus Bacillus as a cluster separate from already described species. The similarity of $16 \mathrm{~S}$ rRNA gene sequences among the novel strains was $>99 \%$, but the similarity was only about $97 \%$ with their nearest neighbours Bacillus pocheonensis, Bacillus firmus and Bacillus

bataviensis. DNA-DNA hybridization dissociation values were $<24 \%$ to the closest related type strains. The novel strains had a $\mathrm{G}+\mathrm{C}$ content $35.6 \pm 0.5 \mathrm{~mol} \%$ and could liquefy gelatin but did not utilize or produce acids from any of the carbon substrates tested. The major fatty acids were iso- $\mathrm{C}_{15: 0}$ and anteiso- $\mathrm{C}_{15: 0}$ and the cell-wall diamino acid was meso-diaminopimelic acid.

Based on phylogenetic and phenotypic results, it is concluded that these strains represent a novel species of the genus Bacillus, for which the name Bacillus horneckiae sp. nov. is proposed. The type strain is $1 \mathrm{P}^{2} 1 \mathrm{SC}^{\top}\left(=\mathrm{NRRL} B-59162^{\top}=\right.$ MTCC $\left.9535^{\top}\right)$.
During microbial diversity surveys performed since 2000, several hundred aerobic microbial strains have been isolated from spacecraft-associated surfaces (NASA, 1980) and characterized for their taxonomic affiliation (Kempf $e t$ al., 2005; La Duc et al., 2004b, c; Venkateswaran et al.,

tPresent address: Lehrstuhl fuer Mikrobiologie und Archaeenzentrum, Universitaet Regensburg, Universtiaetsstrasse 31, D-93053 Regensburg, Germany.

$\ddagger$ Present address: Lawrence Berkeley National Laboratory, Berkeley, CA, USA.

Abbreviations: DAP, diaminopimelic acid; FAME, fatty acid methyl ester. The GenBank/EMBL/DDBJ accession numbers for the 16S rRNA gene sequences of Bacillus horneckiae strains 1P01SC ${ }^{\top}, 1 \mathrm{P02SA}, 1 \mathrm{P08SA}$, 1P10SC and 1P10SEA are EU861362-EU861366, respectively.

Micrographs of the novel strains, 2D TLC of polar lipids and details of rep-PCR-based fingerprinting are available as supplementary material with the online version of this paper. 2003a). The majority of these strains $(85 \%)$ were Grampositive bacteria that almost all belonged to the genus Bacillus. In addition to prevalent species such as Bacillus licheniformis (25\%) and Bacillus pumilus (16\%), several novel species have been described (La Duc et al., 2003; Osman et al., 2006, 2007; Satomi et al., 2006). Although spacecraft-assembly environments are clean, desiccated and controlled for relative humidity (La Duc et al., 2007), the micro-organisms that persist within these facilities frequently demonstrate tolerance to desiccation, chemical oxidizing agents and UV irradiation (La Duc et al., 2003, 2004a, 2007; Venkateswaran et al., 2001). Microbes isolated from these environments are problematic, as they have the potential to adhere to robotic mission flight hardware (Crawford, 2005; La Duc et al., 2004c; Osman et al., 2006; Venkateswaran et al., 2003b) and subsequently to be transferred to other planetary bodies when spacecraft land. 
While characterizing strains isolated from the Payload Hazardous and Servicing Facility (PHSF), in which the Phoenix spacecraft was assembled (Ghosh et al., 2010), five strains were found that possessed external layer-like structures, similar to those noticed in Bacillus nealsonii, that are presumed to enhance the survival of spores under UV irradiation conditions (Venkateswaran et al., 2003b). The isolated strains clustered together based on $16 \mathrm{~S}$ rRNA gene sequence analysis ( $>99 \%$ similarity), yet were distantly related to any previously described Bacillus species $(<97.5 \%$ similarity). Here, we describe the phylogenetic affiliation of these novel strains using a polyphasic taxonomic approach.

The PHSF is a class $100 \mathrm{~K}$, HEPA-filtered clean-room facility, $32.6 \mathrm{~m}$ wide, $18.4 \mathrm{~m}$ long and $28.9 \mathrm{~m}$ high, with a consistently maintained temperature of $21.7 \pm 3.3^{\circ} \mathrm{C}$ and a relative humidity between 39 and $42 \%$. Samples were collected from different locations of the clean-room floor using biological sampling kits (BiSKits; QuickSilver Analytics) as described elsewhere (La Duc et al., 2007). The samples were heat-shocked for $15 \mathrm{~min}$ at $80{ }^{\circ} \mathrm{C}$, as called for by the NASA standard assay, to ensure inactivation of all vegetative cells and enhance detection of spores (NASA, 1980). Samples were then plated on tryptic soy agar (TSA; Difco) and incubated for 2-7 days at $32{ }^{\circ} \mathrm{C}$. The isolated strains described herein were routinely cultured on TSA plates $\left(24 \mathrm{~h}\right.$ at $\left.32{ }^{\circ} \mathrm{C}\right)$ for various analyses. Colonies of all strains were circular, convex, irregularly edged and yellowish in $24 \mathrm{~h}$ old cultures, with no pigmentation even after prolonged incubation.

A modified Schaeffer's medium (MSM) which consisted of $0.1 \% \mathrm{KCl}, 0.012 \% \mathrm{MgCl}_{2}, 1.0 \mathrm{mM} \mathrm{Ca}\left(\mathrm{NO}_{3}\right)_{2}, 0.01 \mathrm{mM}$ $\mathrm{MnCl}_{2}, 0.001 \mathrm{mM} \mathrm{FeSO}$ and $8 \mathrm{~g}$ nutrient broth per litre distilled deionized water, was used to induce sporulation, as described previously (Kempf et al., 2005). A single colony of each strain was inoculated in $10 \mathrm{ml}$ MSM medium and incubated for $24-48 \mathrm{~h}$ at $28{ }^{\circ} \mathrm{C}$ before being subjected to phase-contrast light microscopy (Olympus BX-90). All strains initially showed rod-shaped vegetative cells that occurred singly or in aggregates. Spores purified after $48 \mathrm{~h}$ growth and vegetative cells with subterminal endospores or sporangia (Supplementary Fig. S1a, available in IJSEM Online) exhibited either single or aggregated forms. Scanning electron microscopy (NOVA nanoSEM600; EDAX) was used to determine the morphology of the cells and spores in detail (Cole \& Popkin, 1981). As shown in Supplementary Fig. S1(b, d), spores exhibited an external layer that appeared to attract other spores and result in the formation of a biofilm or aggregates. Transmission electron microscopy (Supplementary Fig. S1c) confirmed that these structures are not exosporia, as observed in Bacillus odysseyi (La Duc et al., 2004c), but are loosely attached external layers around the spore coat, similar to those seen in B. nealsonii (Venkateswaran et al., 2003b). Unlike B. nealsonii, however, spores of the novel strains exhibited a tendency to attach to one another, although spore aggregates could be separated by incubating spore solutions in 50\% ethanol for 10-15 min (not shown). Further chemical characterization of the external layer is not reported here as it is beyond the scope of this communication.

All strains showed about $99 \%$ sporulation when grown for 2 days at $32{ }^{\circ} \mathrm{C}$ and were harvested to study their resistance to $\mathrm{UV}_{254}$ (Newcombe et al., 2005). The cultures were washed with sterile PBS (pH 7.4) and diluted in sterile PBS to obtain an $\mathrm{OD}_{600}$ of 0.1 (equivalent to about $10^{6}$ spores $\mathrm{ml}^{-1}$ ). Appropriate aliquots of the spore suspension were placed in uncovered sterile Petri dishes and exposed to $\mathrm{UV}_{254}$ radiation $\left(0,200,500,1000\right.$ and $\left.1500 \mathrm{~J} \mathrm{~m}^{-2}\right)$ using a hand-held UV instrument at a fixed distance (Newcombe et al., 2005). At appropriate intervals, $100 \mu \mathrm{l}$ aliquots of the reaction mixtures were removed, inoculated into $5 \mathrm{ml}$ tryptic soy broth (TSB; Difco) and incubated at $32{ }^{\circ} \mathrm{C}$ for 2-5 days. All strains were resistant up to $1000 \mathrm{~J} \mathrm{~m}^{-2}$ and were about five times more resistant than the well-studied spores of Bacillus subtilis (Newcombe et al., 2005).

A number of metabolic assays were performed to evaluate the novel strains. Biochemical tests to characterize phenotypes were carried out using API 20NE and API 50CH test strips with API 50CHB suspension medium (bioMérieux) according to the manufacturer's instructions. The results of carbon substrate utilization and acid production tests are given in Table 1. API 20NE tests were used to determine nitrate reduction, aesculin hydrolysis, $\beta$-galactosidase production, fermentation of glucose, the ONPG test ( $\beta$-galactosidase), urease, gelatinase and indole production. API 50CHB was used to determine acid production from and assimilation of carbohydrates. The ability of the strains to grow in varying concentrations of $\mathrm{NaCl}(0-20 \% \mathrm{w} / \mathrm{v})$ was determined in $1 \%(\mathrm{w} / \mathrm{v})$ Bacto tryptone prepared in deionized water as basal medium, with increasing concentrations of $\mathrm{NaCl}$ (Venkateswaran et al., 1999). A single colony was suspended in sterile tryptone water and used for inoculation, and growth was assessed after 5 days of incubation at $32{ }^{\circ} \mathrm{C}$. Compared with their nearest neighbour Bacillus pocheonensis, which is able to grow at up to $12 \%$ $(\mathrm{w} / \mathrm{v}) \mathrm{NaCl}$, all five novel strains were only able to grow in 0 $10 \%(\mathrm{w} / \mathrm{v}) \mathrm{NaCl}$, and were considered to be halotolerant. Growth at varying $\mathrm{pH}$ was determined as described previously (La Duc et al., 2007). Sterile TSA was adjusted to $\mathrm{pH} 3,9,10.8$ and 13 after autoclaving using $0.5 \mathrm{M}$ sterile citric acid or $10 \%(\mathrm{w} / \mathrm{v}) \mathrm{Na}_{2} \mathrm{CO}_{3}$ as appropriate. A single colony of each strain was streaked onto appropriate plates and incubated for 5 days at $32{ }^{\circ} \mathrm{C}$. All strains showed growth at $\mathrm{pH} \mathrm{7,9}$ and 10.8 but not at $\mathrm{pH} 3$ or 13. Growth at different temperatures was assessed in TSB; inoculated cultures were incubated at $4,10,32$ and $50{ }^{\circ} \mathrm{C}$. All five novel strains showed growth at $4-32{ }^{\circ} \mathrm{C}$ after incubation for 7 days. Phenotypic characteristics that distinguish the novel strains readily from the closely related $B$. pocheonensis type strain are motility, growth in $0.5 \% \mathrm{NaCl}$ (TSA), tolerance of $\mathrm{pH}$ 9.0, liquefaction of gelatin and the inability to hydrolyse aesculin and to produce acids from a variety of sugars. Other differential phenotypic characteristics are shown in Table 1. 
Table 1. Differential characteristics of the five novel strains and type strains of related Bacillus species

Strains: 1, 1P01SC ${ }^{\mathrm{T}}$, 1P08SA, 1P10SC, 1P10SE and 1P02SA (B. horneckiae sp. nov.); 2, B. pocheonensis DSM 18135 ${ }^{\mathrm{T}}$; 3, B. drentensis DSM 15600 ${ }^{\mathrm{T}}$; 4 , B. novalis DSM $15603^{\mathrm{T}}$; 5, B. firmus IAM $12464^{\mathrm{T}} ; 6$, B. niacini DSM $2923^{\mathrm{T}} ; 7$, B. bataviensis DSM $15601^{\mathrm{T}}$. All data were obtained in this study. All strains showed negative reactions for indole production, urease, assimilation of capric acid and phenylacetic acid and activities of lipase, valine arylamidase, cystine arylamidase, trypsin, $\alpha$-mannosidase and $\alpha$-fucosidase and positive reactions for catalase and nitrate reduction. + , Positive; - , negative; ND, not determined; $v$, variable; $w$, weak.

\begin{tabular}{|c|c|c|c|c|c|c|c|}
\hline Characteristic & 1 & 2 & 3 & 4 & 5 & 6 & 7 \\
\hline Growth at $50{ }^{\circ} \mathrm{C}$ & - & - & + & + & - & - & + \\
\hline Maximum pH & 10.8 & 8.5 & 10 & 10 & 10.5 & 8 & 10 \\
\hline Maximum $\mathrm{NaCl}$ concentration $(\% \mathrm{w} / \mathrm{v})$ & 10 & 12 & $\mathrm{ND}$ & $\mathrm{ND}$ & 10 & ND & ND \\
\hline Growth in the absence of $\mathrm{NaCl}$ & + & + & $\mathrm{ND}$ & $\mathrm{ND}$ & - & $\mathrm{ND}$ & ND \\
\hline \multicolumn{8}{|l|}{ API 20NE tests } \\
\hline Glucose fermentation & - & - & - & $\mathrm{w}$ & + & - & - \\
\hline Arginine dihydrolase & - & - & + & - & - & - & - \\
\hline$\beta$-Galactosidase production & - & $\mathrm{w}$ & + & + & - & + & + \\
\hline \multicolumn{8}{|l|}{ Hydrolysis of: } \\
\hline L-Arabinose & - & + & - & + & - & + & - \\
\hline D-Glucose & - & + & + & + & + & + & + \\
\hline Malic acid & + & + & - & + & - & + & - \\
\hline Maltose & + & + & + & + & + & + & + \\
\hline D-Mannitol & - & - & - & + & + & - & + \\
\hline D-Mannose & - & + & - & + & - & + & + \\
\hline$N$-Acetyl-D-glucosamine & - & + & + & + & + & + & + \\
\hline Potassium gluconate & + & + & - & + & - & + & + \\
\hline Trisodium citrate & + & $\mathrm{w}$ & - & + & - & - & - \\
\hline \multicolumn{8}{|l|}{ Production of: } \\
\hline Alkaline phosphatase & $\mathrm{w}$ & + & $\mathrm{w}$ & + & - & $\mathrm{w}$ & + \\
\hline$\beta$-Galactosidase & - & + & - & - & - & $\mathrm{w}$ & + \\
\hline$\beta$-Glucuronidase & - & - & + & - & - & - & - \\
\hline$\alpha$-Glucosidase & - & + & - & + & + & - & - \\
\hline$\beta$-Glucosidase & - & $\mathrm{w}$ & - & + & - & - & - \\
\hline$N$-Acetyl- $\beta$-glucosaminidase & - & - & $\mathrm{w}$ & - & - & - & - \\
\hline
\end{tabular}

Cellular fatty acid methyl esters (FAMEs) were analysed using the Microbial ID system (MIDI, Inc.) according to the manufacturer's instructions, which did not identify the novel strains as members of any known Bacillus species. The FAME profiles of all five strains of this study and strains of other closely related Bacillus species are given in Table 2 . The fatty acid profile was not significantly different among the five tested strains and was somewhat similar to that of Bacillus firmus but significantly different from that of any other closely related Bacillus species. iso- $\mathrm{C}_{15: 0}$ was predominant in all five strains, with a relative concentration as high as $61 \%$, and the second most dominant fatty acid was anteiso- $\mathrm{C}_{15: 0}(20 \%)$. The FAME profile of TSAgrown cells of strain $1 \mathrm{P}^{2} 1 \mathrm{SC}^{\mathrm{T}}$ exhibited negligible change in the content of most fatty acids when compared with the FAME profile of R2A-grown cells (not shown). 
Table 2. Fatty acid analysis of strains of $B$. horneckiae and related species of the genus Bacillus

Values are percentages of total fatty acids. Data for the five novel strains (B. horneckiae) and B. niacini DSM $2923^{\mathrm{T}}$ are from this study; data for B. firmus (Kämpfer, 1994), for B. novalis, B. bataviensis and B. drentensis (Heyrman et al., 2004) and for B. subtilis (Kämpfer, 2002) were reproduced from the publications indicated.

\begin{tabular}{|c|c|c|c|c|c|c|c|c|c|c|c|}
\hline Fatty acid & 1P01SC & 1P10SC & 1P10SE & 1P02SA & 1P08SA & $\begin{array}{c}B . \\
\text { firmus }\end{array}$ & $\begin{array}{c}\text { B. } \\
\text { niacini }\end{array}$ & $\begin{array}{c}\text { B. } \\
\text { novalis }\end{array}$ & $\begin{array}{c}\text { B. } \\
\text { bataviensis }\end{array}$ & $\begin{array}{c}\text { B. } \\
\text { drentensis }\end{array}$ & $\begin{array}{c}\text { B. } \\
\text { subtilis }\end{array}$ \\
\hline \multicolumn{12}{|l|}{$\begin{array}{l}\text { Straight-chain } \\
\text { saturated }\end{array}$} \\
\hline $\mathrm{C}_{10: 0}$ & & & 0.1 & & & & 3.6 & & & & \\
\hline $\mathrm{C}_{12: 0}$ & & 0.2 & & & & & 3.6 & & & & \\
\hline \multicolumn{12}{|l|}{$\mathrm{C}_{13: 0}$} \\
\hline $\mathrm{C}_{14: 0}$ & 1.1 & 0.4 & 0.4 & 0.5 & 0.4 & 1.1 & 4.8 & 3.0 & 1.5 & 1.4 & \\
\hline $\mathrm{C}_{15: 0}$ & & 1.3 & 1.4 & 1.3 & 1.4 & 0.3 & & & & & \\
\hline $\mathrm{C}_{16: 0}$ & 0.5 & 0.4 & 1.0 & 1.0 & 1.1 & 1.5 & 11.7 & 4.8 & 7.7 & 3.4 & 1.0 \\
\hline $\mathrm{C}_{18: 0}$ & & & & & & 0.1 & & $<1.0$ & 2.7 & 1.3 & \\
\hline \multicolumn{12}{|l|}{ Branched saturated } \\
\hline iso- $\mathrm{C}_{13: 0}$ & 0.2 & & 0.2 & & & & & & & & \\
\hline iso- $\mathrm{C}_{14: 0}$ & 4.0 & 2.6 & 2.6 & 2.5 & 2.2 & 2.4 & 3.5 & 5.3 & 6.9 & 8.7 & 1.0 \\
\hline iso- $\mathrm{C}_{15: 0}$ & 54.3 & 56.8 & 60.7 & 51.1 & 53.3 & 45.8 & 41.2 & 43.9 & 36.9 & 32.2 & 27.0 \\
\hline iso- $\mathrm{C}_{16: 0}$ & 2.5 & 1.5 & 2.5 & 3.0 & 2.9 & 2.9 & 7.3 & 2.7 & 2.4 & 2.1 & 1.0 \\
\hline iso- $\mathrm{C}_{17: 0}$ & 1.3 & 1.9 & 1.8 & 1.9 & 1.5 & 2.9 & 4.7 & $<1.0$ & 1.4 & 2.6 & 8.0 \\
\hline anteiso- $\mathrm{C}_{15: 0}$ & 19.9 & 18.4 & 16.9 & 17.6 & 19.0 & 19.8 & 14.2 & 31.0 & 20.5 & 21.8 & 39.0 \\
\hline anteiso- $\mathrm{C}_{17: 0}$ & 2.3 & 2.6 & 3.4 & 4.2 & 3.5 & 3.7 & 5.0 & 1.9 & 1.1 & 1.1 & 1.0 \\
\hline \multicolumn{12}{|l|}{ Monounsaturated } \\
\hline $\mathrm{C}_{16: 1} \omega 11 c$ & 2.0 & 2.8 & 2.8 & 3.7 & 3.9 & 3.2 & & 3.2 & 11.3 & 13.2 & \\
\hline $\begin{array}{l}\mathrm{C}_{16: 1} \omega 7 c \text { alcohol } \\
\text { iso- } \mathrm{C}_{17: 1}\end{array}$ & 6.8 & 5.6 & 6.0 & 6.7 & 5.2 & 4.5 & & 1.7 & 2.3 & 3.1 & 3.0 \\
\hline $\begin{array}{l}\text { iso- } \mathrm{C}_{17: 1} \omega 10 c \\
\text { anteiso- } \mathrm{C}_{17: 1}\end{array}$ & 2.3 & 2.6 & 2.7 & 3.3 & 3.9 & 0.1 & & $<1.0$ & 1.7 & 4.5 & 10.0 \\
\hline Unknown fatty acids & 2.9 & 3.9 & 3.0 & 3.9 & 3.6 & 8.4 & & $<1.0$ & $<1.0$ & $<1.0$ & \\
\hline
\end{tabular}

The diastereoisomer of diaminopimelic acid (DAP) in cellwall hydrolysates of strains 1 P01SC ${ }^{\mathrm{T}}$ and 1P08SA was determined (Staneck \& Roberts, 1974). Briefly, $20 \mathrm{mg}$ freeze-dried cells was hydrolysed with $200 \mu \mathrm{l} 6 \mathrm{M} \mathrm{HCl}$ in a $100{ }^{\circ} \mathrm{C}$ water bath for $18 \mathrm{~h}$. Following hydrolysis, the cell mixture was filtered through an activated charcoal column and dried completely in a concentrator (Turbo-Vap; Zymarck) and then dissolved in $200 \mu \mathrm{l}$ sterile double-distilled water. A total of $5 \mu \mathrm{l}$ hydrolysate was applied on a TLC plate (Merck 5577) along with standards (LL-DAP and meso-DAP) and developed in a two-dimensional TLC tank containing methanol/water/10 M HCl/pyridine $(80: 17.5: 2.5: 10$, by vol.) for $3 \mathrm{~h}$. The TLC plate was dried under a fume hood and sprayed with $0.2 \%$ ninhydrin solution. The plates were finally heated to $100-105{ }^{\circ} \mathrm{C}$. After about 5 min, DAP was visualized as a grey-green colour when compared against the standard DAP. Analysis of cell-wall hydrolysates of strains $1 \mathrm{P}^{2} 1 \mathrm{SC}^{\mathrm{T}}$ and 1P08SA revealed the presence of meso-DAP as the diagnostic cell-wall diamino acid, which was also present in other Bacillus type strains analysed in this study (not shown).

Extraction (Bligh \& Dyer, 1959) and identification (Komagata \& Suzuki, 1987) of polar lipids were carried out according to established procedures. Lipid spots were detected using the following spray reagents: molybdato- phosphoric acid $(5 \%, \mathrm{w} / \mathrm{v}$, in absolute ethanol), molybdenum blue spray reagent (Sigma), ninhydrin $(0.2 \%$, $\mathrm{w} / \mathrm{v}$, in acetone) and anisaldehyde reagent (Sigma) for detection of total lipids, phospholipids, aminolipids and glycolipids, respectively. Strains $1 \mathrm{P}^{\mathrm{P}} 1 \mathrm{SC}^{\mathrm{T}}$ and 1P08SA displayed a complex polar lipid profile, which consisted of seven unknown phospholipids, two unknown aminolipids and one unknown aminophospholipid (Supplementary Fig. S2). The lipid profiles of strains $1 \mathrm{P} 01 \mathrm{SC}^{\mathrm{T}}$ and 1P08SA are quite similar to each other (10 out of a total of 14 spots detected in both). One of the unknown aminolipids and the seven phospholipids are seen in both strains but were not reported for B. subtilis. However, the major lipids of these two strains are somewhat similar to the profile of B. subtilis (Table 3). Respiratory quinones were extracted according to established methods (Nakagawa \& Yamasato, 1993), and MK-7 was dominant in strains $1 \mathrm{P}^{2} 1 \mathrm{SC}^{\mathrm{T}}$ and 1P08SA. Based on the cell-wall composition, menaquinone analyses and major polar lipids, the newly described strains belong to Bacillus (Table 3).

Genomic DNA was isolated from strain $1 \mathrm{P} 01 \mathrm{SC}^{\mathrm{T}}$ and other type strains (detailed below) using established techniques (Johnson, 1981). The G $+\mathrm{C}$ content of the novel strains was determined spectrophotometrically (Lambda 35; 
Table 3. Characteristics that distinguish Bacillus horneckiae sp. nov. from related genera

Data for B. horneckiae are from this study; data for B. subtilis (Kämpfer, 1994), Viridibacillus (Albert et al., 2007), Kurthia (Shaw \& Keddie, 1983), Lysinibacillus (Ahmed et al., 2007) and Rummeliibacillus (Vaishampayan et al., 2009) were taken from the publications indicated.

\begin{tabular}{|c|c|c|c|c|c|c|}
\hline Characteristic & B. horneckiae & B. subtilis & Viridibacillus & Kurthia & Lysinibacillus & Rummeliibacillus \\
\hline Spore formation & Present & Present & Present & Absent & Present & Present \\
\hline $\begin{array}{l}\text { Cell-wall } \\
\text { composition }\end{array}$ & meso-DAP & meso-DAP & $\begin{array}{c}\text { L-Lys-D-Glu or } \\
\text { L-Lys-D-Asp }\end{array}$ & $\begin{array}{l}\text { L-Lys- } \\
\text { D-Asp }\end{array}$ & Lys-Asp & $\begin{array}{l}\text { L-Lys-D-Glu } \\
\text { or Lys-Asp }\end{array}$ \\
\hline $\begin{array}{l}\text { Green pigment } \\
\text { formation }\end{array}$ & Absent & Absent & Present & Absent & Absent & Absent \\
\hline Major fatty acids $\dagger$ & $\mathrm{i}-\mathrm{C}_{15: 0}$, ai- $-\mathrm{C}_{15: 0}$ & $\begin{array}{l}\text { i- } C_{15: 0}, \text { ai }-C_{15: 0} \\
\text { ai- } C_{17: 1}\end{array}$ & $\begin{array}{l}\text { i- } C_{15: 0} \\
\quad\left(\text { ai- } C_{15: 0}\right)\end{array}$ & $\begin{array}{l}\text { i- } C_{15: 0} \\
\text { ai- } C_{15: 0}\end{array}$ & $\begin{array}{l}\text { i- } C_{15: 0},\left(\text { ai- }-C_{15: 0}, \quad,-C_{16: 0}\right. \\
\left.\text { ai- } C_{17: 0}, C_{16: 1} \omega 7 c \text { alcohol }\right)\end{array}$ & $\begin{array}{l}\text { i- } C_{15: 0} \\
\text { ai- } C_{15: 0}\end{array}$ \\
\hline
\end{tabular}

*AL, Unknown aminolipid; APGL, unknown aminophosphoglycolipid; APL, unknown aminophospholipid; DPG, diphosphatidylglycerol; GBG, gentiobiosyldiacylglycerol; PE, phosphatidylethanolamine; PG, phosphatidylglycerol; PL, unknown phospholipid.

$\dagger$ †i, Anteiso-branched; i, iso-branched. Compounds making up more than $20 \%$ of the total fatty acids; compounds present at $10-20 \%$ are indicated in parentheses.

Perkin Elmer) as $35.6 \pm 0.5 \mathrm{~mol} \%$ using a thermal denaturation method (Mandel \& Marmur, 1968). The 16S rRNA gene was amplified by PCR using a universal primer set and sequenced bidirectionally as reported elsewhere (La Duc et al., 2007). The 16S rRNA gene sequence (about $1.4 \mathrm{~kb}$ ) was compared to publicly available sequences using BLAST. Neighbour-joining phylogenetic analysis was performed using the ARB software package (Ludwig et al., 2004). Sequence similarities between the five novel strains were 99.5-100\%, and the strains formed a well-defined and separate cluster supported by high bootstrap values (Fig. 1). The sequences of the novel strains formed a separate cluster with a dissimilarity of more than $2.5 \%$ from several other Bacillus species. B. pocheonensis Gsoil $420^{\mathrm{T}}$ exhibited the highest 16S rRNA gene sequence similarity $(97.5 \%)$ to strain 1P01SC ${ }^{\mathrm{T}}$. Strains of all other Bacillus species with validly published names demonstrated sequence similar- ities of $97.3 \%$ or less; notably, the similarity was only $93.8 \%$ with the type strain of $B$. subtilis, the type species of the genus Bacillus. Close relatives included the type strains of Bacillus niacini (97.3\%), B. firmus (97.3\%), Bacillus bataviensis (97.2\%) and Bacillus drentensis (97.1\%).

DNA-DNA hybridization of $1 \mathrm{P}^{2} 1 \mathrm{SC}^{\mathrm{T}}$ and type strains of various closely related Bacillus species was performed with freshly isolated genomic DNA and was carried out in quadruplicate using the membrane filter method (Tourova \& Antonov, 1987). Means of the three most confident readings were taken for calculation purposes. Strain 1P01SC ${ }^{\mathrm{T}}$ exhibited $87.8 \%$ DNA-DNA relatedness to strain 1P08SA, $24.3 \%$ to $B$. niacini MTCC $9480^{\mathrm{T}}, 7.6 \%$ to B. pocheonensis DSM $18135^{\mathrm{T}}, 5.2 \%$ to B. firmus MTCC $488^{\mathrm{T}}, 3.3 \%$ to B. drentensis MTCC $9481^{\mathrm{T}}, 2.5 \%$ to Bacillus soli MTCC $9482^{\mathrm{T}}$ and $1.5 \%$ to B. bataviensis MTCC $7309^{\mathrm{T}}$. The low $(<70 \%)$ DNA-DNA relatedness between the novel strains and their close relatives precludes genomic

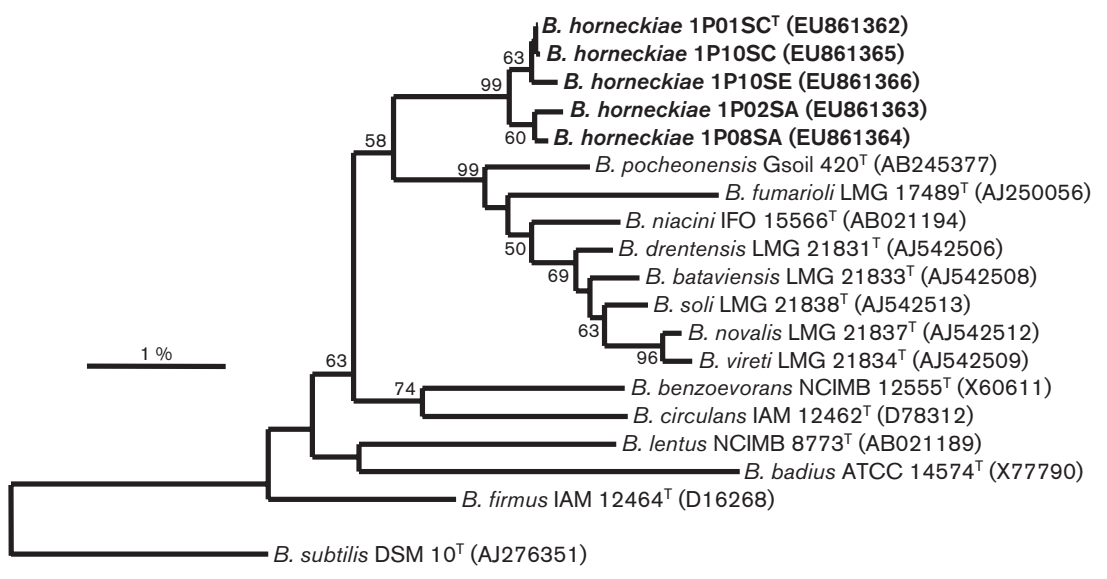

Fig. 1. Phylogenetic tree for strains of Bacillus horneckiae sp. nov. and other closely related Bacillus species based on neighbourjoining analysis of the 16S rRNA gene nucleotide sequence. Strain numbers and GenBank accession numbers (in parentheses) are shown. Bootstrap percentages based on 1000 replications $(\geqslant 50 \%)$ are shown at branch points. Bar, $1 \%$ sequence divergence. 
relatedness at the species level and supports the designation of strains $1 \mathrm{P}^{\mathrm{P}} 1 \mathrm{SC}^{\mathrm{T}}$ and 1P08SA as representatives of a novel species within the genus Bacillus (Stackebrandt \& Goebel, 1994; Wayne, 1988).

In order to elucidate the genotypic variation among the five strains, extracted DNA was amplified using the Bacillus DiversiLab DNA fingerprinting kit (Spectral Genomics, Inc.) according to the protocol established by Healy et al. (2005). The detailed report and resulting dendrogram are given in Supplementary Fig. S3. Strain $1 \mathrm{P} 01 \mathrm{SC}^{\mathrm{T}}$ clustered together with strain 1P10SC and formed the first genospecies, a second cluster consisted of strains 1P02SA and 1P08SA and strain 1P10SE was the sole member of the third genospecies. A similar clustering pattern of the five strains was also noticed in the 16S rRNA gene sequence analysis (Fig. 1).

The results of DNA-DNA hybridization combined with phenotypic comparisons indicate that all five isolates belong to the genus Bacillus but are significantly distinct from any previously described species. Based on the data described herein, the five strains represent a novel species, for which the name Bacillus horneckiae sp. nov. is proposed.

\section{Description of Bacillus horneckiae sp. nov.}

Bacillus horneckiae (hor.nec'ki.ae. N.L. gen. fem. n. horneckiae of Horneck, named after Dr Gerda Horneck, a German space microbiologist who carried out pioneering work in exposing spores to several space and radiation conditions).

Vegetative cells are rod-shaped, $1-1.5 \mu \mathrm{m}$ in diameter and 4-6 $\mu \mathrm{m}$ long, motile and Gram-stain-positive and form endospores that are subterminal in position. Grows under aerobic conditions only. Catalase is produced. Colonies formed after $24 \mathrm{~h}$ of growth on TSA at $32{ }^{\circ} \mathrm{C}$ are yellowish, plain, $3 \mathrm{~mm}$ in diameter, show no pigmentation and possess irregular edges. Optimum growth temperature is $30{ }^{\circ} \mathrm{C}$; known strains do not grow below $4{ }^{\circ} \mathrm{C}$ or at $50{ }^{\circ} \mathrm{C}$. Cells grow in the absence of $\mathrm{NaCl}$ and with up to $10 \%(\mathrm{w} / \mathrm{v})$ $\mathrm{NaCl}$ and up to $\mathrm{pH} 10.8$ with optimum growth at $\mathrm{pH}$ 7.0. Produces oval spores in MSM which are resistant to UV radiation up to $1000 \mathrm{~J} \mathrm{~m}^{-2}$. Reduces nitrates to nitrites and hydrolyses gelatin. Tests for oxidase, indole production, fermentation of glucose, arginine dihydrolase, urease, hydrolysis of aesculin and $\beta$-galactosidase (ONPG) are negative. Assimilates the following as sole carbon sources: maltose, potassium gluconate, adipic acid, malic acid and trisodium citrate. D-Glucose, L-arabinose, D-mannose, D-mannitol, $N$-acetylglucosamine, decanoic acid and 2-phenylacetic acid are not assimilated. Acid is not produced from the following substrates: glycerol, erythritol, D- and L-arabinose, D-ribose, D-xylose, D-adonitol, methyl $\beta$-D-xylopyranoside, D-galactose, D-glucose, D-fructose, D-mannose, L-sorbose, L-rhamnose, dulcitol, inositol, D-mannitol, D-sorbitol, methyl $\alpha$-D-mannopyranoside, methyl $\alpha$-D-glucopyranoside, $N$-acetylglucosamine, amyg- dalin, arbutin, aesculin, salicin, cellobiose, maltose, lactose, melibiose, sucrose, trehalose, inulin, melezitose, raffinose, starch, glycogen, xylitol, gentiobiose, turanose, D-lyxose, D-tagatose, D- and L-fucose, D- and L-arabitol, gluconate, 2-ketogluconate and 5-ketogluconate. Gelatin liquefaction is positive for strains $1 \mathrm{P} 01 \mathrm{SC}^{\mathrm{T}}$ and $1 \mathrm{P} 02 \mathrm{SA}$ and weakly positive for three other strains. The major fatty acid of strains $1 \mathrm{P} 01 \mathrm{SC}^{\mathrm{T}}$ and 1P08SA is iso- $\mathrm{C}_{15: 0}$. The diagnostic diamino acid in the peptidoglycan is meso-DAP. The DNA $\mathrm{G}+\mathrm{C}$ content of the type strain is $35.6 \pm 0.5 \mathrm{~mol} \%$.

The type strain, $1 \mathrm{P} 1 \mathrm{SC}^{\mathrm{T}}\left(=\mathrm{NRRL} \mathrm{B}-59162^{\mathrm{T}}=\mathrm{MTCC}\right.$ $9535^{\mathrm{T}}$ ), was isolated from surfaces of the PHSF located at the Kennedy Space Center, where the Phoenix spacecraft was assembled. Strains 1P08SA (=MTCC 9536), 1P10SC, 1P10SE and 1P02SA are additional strains of the species, isolated from the same source.

\section{Acknowledgements}

The research described in this publication was carried out at the Jet Propulsion Laboratory, California Institute of Technology, under a contract with the National Aeronautics and Space Administration. This research was funded by a 2007 NRA ROSES grant. We are grateful to J. Rummel and C. Conley for useful discussions, J. A. Spry for encouragement and all of the members of the JPL Biotechnology and Planetary Protection Group for technical assistance. S. Frye and R. Casey from the Diversi Lab, Houston, TX, and M. Ott from the Johnson Space Center are acknowledged for genotyping of the isolates.

\section{References}

Ahmed, I., Yokota, A., Yamazoe, A. \& Fujiwara, T. (2007). Proposal of Lysinibacillus boronitolerans gen. nov., sp. nov., and transfer of Bacillus fusiformis to Lysinibacillus fusiformis comb. nov. and Bacillus sphaericus to Lysinibacillus sphaericus comb. nov. Int J Syst Evol Microbiol 57, 1117-1125.

Albert, R. A., Archambault, J., Lempa, M., Hurst, B., Richardson, C., Gruenloh, S., Duran, M., Worliczek, H. L., Huber, B. E. \& other authors (2007). Proposal of Viridibacillus gen. nov. and reclassification of Bacillus arvi, Bacillus arenosi and Bacillus neidei as Viridibacillus arvi gen. nov., comb. nov., Viridibacillus arenosi comb. nov. and Viridibacillus neidei comb. nov. Int J Syst Evol Microbiol 57, 2729-2737.

Bligh, E. G. \& Dyer, W. J. (1959). A rapid method of total lipid extraction and purification. Can J Biochem Physiol 37, 911-917.

Cole, R. M. \& Popkin, T. J. (1981). Electron microscopy. In Manual of Methods for General Bacteriology, pp. 34-51. Edited by P. Gerhardt, R. G. E. Murray, R. N. Costilaw, E. W. Nester, W. A. Wood, N. R. Krieg \& G. B. Phillips. Washington, DC: American Society for Microbiology.

Crawford, R. L. (2005). Microbial diversity and its relationship to planetary protection. Appl Environ Microbiol 71, 4163-4168.

Ghosh, S., Osman, S., Vaishampayan, P. \& Venkateswaran, K. (2010). Recurrent isolation of extremo-tolerant bacteria from the clean room where Phoenix spacecraft components are assembled. Astrobiology (in press).

Healy, M., Huong, J., Bittner, T., Lising, M., Frye, S., Raza, S., Schrock, R., Manry, J., Renwick, A. \& other authors (2005). Microbial 
DNA typing by automated repetitive-sequence-based PCR. J Clin Microbiol 43, 199-207.

Heyrman, J., Vanparys, B., Logan, N. A., Balcaen, A., Rodriguez-Diaz, M., Felske, A. \& De Vos, P. (2004). Bacillus novalis sp. nov., Bacillus vireti sp. nov., Bacillus soli sp. nov., Bacillus bataviensis sp. nov. and Bacillus drentensis sp. nov., from the Drentse A grasslands. Int J Syst Evol Microbiol 54, 47-57.

Johnson, J. L. (1981). Genetic characterization. In Manual of Methods for General Bacteriology, pp. 450-472. Edited by P. Gerhardt, R. G. E. Murray, R. N. Costilaw, E. W. Nester, W. A. Wood, N. R. Krieg \& G. B. Phillips. Washington, DC: American Society for Microbiology. Kämpfer, P. (1994). Limits and possibilities of total fatty acid analysis for classification and identification of Bacillus species. Syst Appl Microbiol 17, 86-98.

Kämpfer, P. (2002). Whole-cell fatty acid analysis in the systematics of Bacillus and related genera. In Applications and Systematics of Bacillus and Relatives, pp. 271-299. Edited by R. Berkeley, M. Heyndrickx, N. Logan \& P. De Vos. Oxford: Blackwell Science.

Kempf, M. J., Chen, F., Kern, R. \& Venkateswaran, K. (2005). Recurrent isolation of hydrogen peroxide-resistant spores of Bacillus pumilus from a spacecraft assembly facility. Astrobiology 5, 391-405.

Komagata, K. \& Suzuki, K. (1987). Lipid and cell-wall analysis in bacterial systematics. Methods Microbiol 19, 161-207.

La Duc, M. T., Nicholson, W., Kern, R. \& Venkateswaran, K. (2003). Microbial characterization of the Mars Odyssey spacecraft and its encapsulation facility. Environ Microbiol 5, 977-985.

La Duc, M. T., Kern, R. \& Venkateswaran, K. (2004a). Microbial monitoring of spacecraft and associated environments. Microb Ecol 47, 150-158.

La Duc, M. T., Satomi, M., Agata, N. \& Venkateswaran, K. (2004b). gyrB as a phylogenetic discriminator for members of the Bacillus anthracis-cereus-thuringiensis group. J Microbiol Methods 56, 383-394.

La Duc, M. T., Satomi, M. \& Venkateswaran, K. (2004c). Bacillus odysseyi sp. nov., a round-spore-forming bacillus isolated from the Mars Odyssey spacecraft. Int J Syst Evol Microbiol 54, 195-201.

La Duc, M. T., Dekas, A. E., Osman, S., Moissl, C., Newcombe, D. \& Venkateswaran, K. (2007). Isolation and characterization of bacteria capable of tolerating the extreme conditions of clean-room environments. Appl Environ Microbiol 73, 2600-2611.

Ludwig, W., Strunk, O., Westram, R., Richter, L., Meier, H., Yadhukumar, Buchner, A., Lai, T., Steppi, S. \& other authors (2004). ARB: a software environment for sequence data. Nucleic Acids Res 32, 1363-1371.

Mandel, M. \& Marmur, J. (1968). Use of ultraviolet absorbancetemperature profile for determining the guanine plus cytosine content of DNA. Methods Enzymol 12B, 195-206.

Nakagawa, Y. \& Yamasato, K. (1993). Phylogenetic diversity of the genus Cytophaga revealed by $16 \mathrm{~S}$ rRNA sequencing and menaquinone analysis. J Gen Microbiol 139, 1155-1161.

NASA (1980). Standard procedures for the microbiological examination of space hardware, NHB 5340.1B, Rev. B. Washington, DC: National Aeronautics and Space Administration.
Newcombe, D. A., Schuerger, A. C., Benardini, J. N., Dickinson, D., Tanner, R. \& Venkateswaran, K. (2005). Survival of spacecraftassociated microorganisms under simulated martian UV irradiation. Appl Environ Microbiol 71, 8147-8156.

Osman, S., Satomi, M. \& Venkateswaran, K. (2006). Paenibacillus pasadenensis sp. nov. and Paenibacillus barengoltzii sp. nov., isolated from a spacecraft assembly facility. Int J Syst Evol Microbiol 56, 15091514.

Osman, S., Moissl, C., Hosoya, N., Briegel, A., Mayilraj, S., Satomi, M. \& Venkateswaran, K. (2007). Tetrasphaera remsis sp. nov., isolated from the Regenerative Enclosed Life Support Module Simulator (REMS) air system. Int J Syst Evol Microbiol 57, 2749-2753.

Satomi, M., La Duc, M. T. \& Venkateswaran, K. (2006). Bacillus safensis sp. nov., isolated from spacecraft and assembly-facility surfaces. Int J Syst Evol Microbiol 56, 1735-1740.

Shaw, S. \& Keddie, R. M. (1983). A numerical taxonomic study of the genus Kurthia with a revised description of Kurthia zopfii and a description of Kurthia gibsonii sp. nov. Syst Appl Microbiol 4, 253-276.

Stackebrandt, E. \& Goebel, B. M. (1994). Taxonomic note: a place for DNA-DNA reassociation and $16 \mathrm{~S}$ rRNA sequence analysis in the present species definition in bacteriology. Int J Syst Bacteriol 44, 846849.

Staneck, J. L. \& Roberts, G. D. (1974). Simplified approach to identification of aerobic actinomycetes by thin-layer chromatography. Appl Microbiol 28, 226-231.

Tourova, T. P. \& Antonov, A. S. (1987). Identification of microorganisms by rapid DNA-DNA hybridization. Methods Microbiol 19, 333355.

Vaishampayan, P., Miyashita, M., Ohnishi, A., Satomi, M., Rooney, A., La Duc, M. T. \& Venkateswaran, K. (2009). Description of Rummeliibacillus stabekisii gen. nov., sp. nov. and reclassification of Bacillus pycnus Nakamura et al. 2002 as Rummeliibacillus pycnus comb. nov. Int J Syst Evol Microbiol 59, 1094-1099.

Venkateswaran, K., Moser, D. P., Dollhopf, M. E., Lies, D. P., Saffarini, D. A., MacGregor, B. J., Ringelberg, D. B., White, D. C., Nishijima, M. \& other authors (1999). Polyphasic taxonomy of the genus Shewanella and description of Shewanella oneidensis sp. nov. Int J Syst Bacteriol 49, 705-724.

Venkateswaran, K., Satomi, M., Chung, S., Kern, R., Koukol, R., Basic, C. \& White, D. (2001). Molecular microbial diversity of a spacecraft assembly facility. Syst Appl Microbiol 24, 311-320.

Venkateswaran, K., Hattori, N., La Duc, M. T. \& Kern, R. (2003a). ATP as a biomarker of viable microorganisms in clean-room facilities. J Microbiol Methods 52, 367-377.

Venkateswaran, K., Kempf, M., Chen, F., Satomi, M., Nicholson, W. \& Kern, R. (2003b). Bacillus nealsonii sp. nov., isolated from a spacecraft-assembly facility, whose spores are gamma-radiation resistant. Int J Syst Evol Microbiol 53, 165-172.

Wayne, L. G. (1988). International Committee on Systematic Bacteriology: announcement of the report of the ad hoc Committee on Reconciliation of Approaches to Bacterial Systematics. Zentralbl Bakteriol Mikrobiol Hyg [A] 268, 433-434. 